\title{
CpG Motif in Phage Genome DNA Enhanced the Efficacy of Phage Therapy by Immunostimulation
}

\author{
Zhabiz Golkar $^{1}$, Nusrat Jamil ${ }^{2}$ \\ 1. South Carolina Center for Biotechnology, Claflin University, Orangeburg, SC 2. Department of \\ Microbiology, University of Karachi, Karachi, 75270, Pakistan
}

$\square$ Corresponding author: Zhabiz Golkar, zgolkar@claflin.edu

Disclosures can be found in Additional Information at the end of the article

Review began 10/12/2012 Published 10/18/2012

\section{(๑) Copyright 2012}

Golkar et al. This is an open access article distributed under the terms of the Creative Commons Attribution License CC-BY 3.0., which permits unrestricted use, distribution, and reproduction in any medium, provided the original author and source are credited.

\section{Abstract}

Lytic phages for multiple-drug resistant E. coli and Pseudomonas aeruginosa were isolated. They belong to Siphoviridea and Myoviridea families, respectively. Lytic life cycle of the phage has therapeutic implications. Concurrent immune-stimulation of adaptive immunity against the etiologic agent, the MDR bacteria in the victim would revolutionize the field of phage therapy. In this pretext, methylated and unmethylated $\mathrm{CpG}$ motifs were identified in genome DNA of these phages by MspI and HpaII restriction fragmentation. To test the immunestimulatory effects, two groups of BALB/c mice and two groups of rabbits were vaccinated with soluble antigen of Salmonella typhi with or without fragmented genome DNA of these phages. In addition, adjuvant efficacy of CpG motifs was compared with mineral oil. In antisera, types of antibodies were determined by immunoelectrophoresis and Western blotting. ELISA was done for quantitative analysis and has shown IgG immunoglobulin was produced by BALB/c and rabbit when fragmented DNA was used as adjuvant. Strong and specific immunogenicity has been attributed to the presence of CpG motifs. However, IgG antibody titer in antiserum raised by Pseudomonas' Phage DNA was high as compared to E. coli . The plausible reason for the variation in immune response is that this DNA has additional AACGAT motifs to enhance immunopotential of its $\mathrm{CpG}$ motifs. Strong and discrete bands were highlighted due to IgG Fab on the Western blots. We predict that efficacy of phage therapy will be enhanced by concurrent immune stimulation with $\mathrm{CpG}$ motif DNA injection with the respective MDR pathogen's antigen for the control of disease.

Categories: Genetics, Internal Medicine, Miscellaneous

Keywords: bacteria, cpg, phage genomes, igg, immunology, immunostimulation, bacterial disease

\section{Introduction}

Prokaryotic DNA, can directly stimulate various arms of the eukaryotic biological defense system, including innate and adaptive immune responses. On the other hand, exposure of vertebrate DNA fails to activate the host immune responses in this manner. Obviously, evolutionarily, such activations of the vertebrate biological defenses make sense. This activation is due to the presence of unmethylated CpG dinucleotides [1], that are generally found in prokaryotic DNA at relatively higher frequency as compared to eukaryotic life forms and even at much less frequency in vertebrates DNA [2]. The bacterial DNA CpG nucleotides can directly stimulate B-lymphocytes, similar to the T-cell independent antigens made up of repeating subunits, i.e. pneumococcal polysacchardides [3-24] as well as activate innate arms of the immune system resulting in activation of monocyte-macrophage and dendritic cells. The later results in amplification of Th1 arm of the immune systems in higher vertebrates secreting 
cytokines and interleukins (i.e. IL-12 and IFN- $\gamma$ ) [3-4]. Several of the cytokines amplified by CpG mediated Th1 activation, subsequently results in increased lytic activity, destroying the invading microbes [4-5]. Of note, CpG DNA induces a Th1-mediated immune activation predominantly is limited to humoral and innate immune activation, sparing the T-cellmediated cellular immune responses [4-5]. One can artificially mimic the CpG type of immune activation by synthetic oligonucleotides (ODN) [6-7] or bacterial plasmid [8] containing high frequency of $\mathrm{CpG}$ motifs. From an evolutionary point of view, it seems logical to hypothesize that rapid Th-1 type of immune activation resulted from exposure to myriad species of bacterial and other prokaryotic life forms that our ancestors likely to encounter on a regular bases during our cave dwelling period. It appears that such $\mathrm{CpG}$ sequences act as auto adjuvant with DNA vaccines, and indeed may even be required for successful induction of immune responses [9]. It is possible to enhance the immune responses of DNA vaccines by selective use of CpG motifs [10]. These strong humoral arms of immune activation are activated through the B cell antigen receptor, and CpG DNA promotes antigen-specific immune response which suggests the utility of $\mathrm{CpG}$ motifs as vaccine adjuvant [11].

\section{Materials And Methods}

Isolation and purification of bacteriophages: The bacteriophages were isolated from the clinical specimen, raw sewage water and lakes by plaque assay and spot assay techniques [12-13].

Isolation of phage from sewage: Coliphage was isolated from a sewage sample by the use of double agar layer technique [14]. Briefly, 10× BHI was used as a developing medium. About 45 $\mathrm{ml}$ of sample was centrifuged at $4000 \mathrm{rpm}$ for $20 \mathrm{~min}$. The pellet was discarded, and the supernatant was further filtered through $0.45 \mu \mathrm{m}$ pore size millipore filters. Into the filtered sterile sample, $5 \mathrm{ml}$ of $10 \times \mathrm{BHI}$ supplemented with $\mathrm{CaCl}_{2}\left(0.5 \mathrm{M}\right.$ final con.), $\mathrm{MgSO}_{4}(0.5 \mathrm{M}$ final con.), and $100 \mu$ l of young growth culture of Escherichia coli and the mixture was incubated in a shaker incubator at $37^{\circ} \mathrm{C}$, overnight.

Isolation of phage from clinical specimen: Urine sample of a UTI patient was centrifuged at $6000 \mathrm{rpm}$, solid matter was removed and was then passed through a $0.45 \mu \mathrm{m}$ pore size nitrocellulose millipore filter. Fifty $\mu \mathrm{l}$ of filtrate, $100 \mu \mathrm{l}$ of culture which grow separately at $37^{\circ} \mathrm{C}$ with continuous shaking at $160 \mathrm{rpm}$ for three to four hours, were added in $3 \mathrm{ml}$ of melted LB soft plain agar and mixed well before plating onto LB agar plates and incubated at $37{ }^{\circ} \mathrm{C}$, overnight. On the following day plaques were picked. All phages isolated were purified by successive single-plaque isolation until homogeneous plaques.

Preparation of Lysate: Isolated colony from overnight culture was grown in LB broth for four hours. A control was run for each reaction. In the control tube, $100 \mu$ of culture, $\mathrm{CaCl}_{2}, \mathrm{MgSO}_{4}$ ( $0.1 \mathrm{M}$ final con.) and $800 \mu \mathrm{l}$ of the remaining LB broth whereas the experimental test tube containing $100 \mu \mathrm{l}$ of culture, $\mathrm{CaCl}_{2}, \mathrm{MgSO}_{4}, 100 \mu \mathrm{l}$ Lysate and $700 \mu \mathrm{l}$ rest LB broth. Both tubes incubated at $37^{\circ} \mathrm{C}$ with shaking at a speed of $160 \mathrm{rpm}$, overnight. After 24 hours, a few drops of $\mathrm{CH}_{3} \mathrm{Cl}$ were added and mixed well through vortexing. Then filter sterilized. All lysates were stored at $4^{\circ} \mathrm{C}$.

Determination of phage interaction with bacteria: Spot assay and plaque assay used to determine the host range of phages and to check the cross infectivity [14]. Respective culture was grown separately at $37^{\circ} \mathrm{C}$ with shaking at $160 \mathrm{rpm}$ for three to four hours. Then, $100 \mu \mathrm{l}$ of young growth culture, $50 \mu \mathrm{l}$ of respective lysate, $\mathrm{CaCl}_{2}$ and $\mathrm{MgSO}_{4}$ were added into the $3 \mathrm{ml}$ of melted LB soft agar tube. Then poured on the LB agar plate and incubated at $37^{\circ} \mathrm{C}$ overnight. While in a spot assay, $10 \mu \mathrm{l}$ of phage lysate was applied on the top layer and incubated at $37^{\circ} \mathrm{C}$, overnight. Control was also ran in which only the lysate was omitted. By this method, phage 
variability and infectivity was checked.

Transmission Electron Microscopy: To study the particle morphology, the lysates were precipitated by using PEG 6000 (Promega Co.) and $\mathrm{NaCl}$ with $8 \%$ and $4 \%$ final concentration, respectively, and were incubated at $4^{\circ} \mathrm{C}$, overnight. These were centrifuged at $14000 \mathrm{rpm}$ for 20 min. where the pellet was resuspended in $100 \mu$ l of double deionized distilled water. Four hundred mesh carbon coated grids were submerged in phage suspension for one minute. Specimen was negatively stained with $2 \%$ uranyl acetate for 30 seconds and examined in a GOEL-JEM-1200 EX II transmission electron microscope.

Phage DNA purification: To $10 \mathrm{ml}$ of lysate, $40 \mu \mathrm{l}$ of nuclease was added and the mixture was incubated at $37^{\circ} \mathrm{C}$ for $15 \mathrm{~min}$, then phage DNA was extracted according to the manufacturer's protocol (Promega Co.).

Restriction endonucleases: Purified phage DNA of PS5Ф, U9Ф and 3S $\Phi$ was digested with, Hpa II, Msp I and Hind III according to the manufacturer's protocols (Promega Co.). Products of the reaction were analyzed by $2 \%$ agarose gel electrophoresis.

Preparation of serological test antigen: Lawn of Salmonella typhi was grown on BHI agar. Bacteria were suspended in $10 \mathrm{ml}$ of distilled water. Cells were heated at $60^{\circ} \mathrm{C}$ for one hr. and then disintegrated in a homogenizer for $15 \mathrm{~min}$. To ensure that all of the bacteria were killed, sodium deoxycholate was added to a final concentration of $1 \%$ (wt/vol) and was concentrated by pressure dialysis.

Antigen concentration using dialysis tube: Dialysis tubing-visking size 3-20 132" was boiled for $10 \mathrm{~min}$ in $10 \mathrm{mM}$ disodium EDTA adjusted to $\mathrm{pH} 7.4$ with $\mathrm{NaOH}$. It was then rinsed several times in sterile deionized distilled water. Ten $\mathrm{ml}$ of antigen suspension was poured in a dialysis tube and then was placed into 250 gm of sucrose (Merk Co.). Pressure dialysis was carried out for two hours to get a final concentration of $5 \mathrm{mg} / \mathrm{ml}$. The supernatant was stored frozen at $-20^{\circ} \mathrm{C}$.

Killed Vaccine preparation: Salmonella typhi was grown on BHI agar. Bacteria were scoped off and suspended in $10 \mathrm{ml}$ of $\mathrm{BHI}$ broth. Cells were heated at $60^{\circ} \mathrm{C}$ for one hour. No growth after plating of heated bacteria on BHI agar indicated that all cells were killed. Cells were centrifuged at 10,000 rpm for $20 \mathrm{~min}$ and the pellet was washed three times with PBS buffer. Pellet was resuspended in sterile distilled water at a concentration of $520 \mu \mathrm{g} / \mathrm{ml}$. Suspension was stored in $-4^{\circ} \mathrm{C}$

Adjuvant vaccine preparation: Adjuvant vaccine was prepared by homogenizing a suspension of $520 \mu \mathrm{g} / \mathrm{ml}$ of heat-killed $S$. typhi with $250 \mu \mathrm{l}$ of mineral oil to form a thick stable emulsion which was injected intermuscularly in rabbit and inter-peritoneally in mice.

Phage DNA vaccine preparation: DNA vaccine was prepared by homogenizing a suspension of $520 \mu \mathrm{g} / \mathrm{ml}$ of heat killed $S$. typhi with $250 \mu \mathrm{l}$ of mineral oil and $16 \mu \mathrm{l}$ of Phage DNA (PS5Ф, U9 Ф).

Preparation of antiserum in rabbit: Before immunization, blood from marginal ear vein of each rabbit was collected. Rabbits were immunized with three doses (each dose after seven days) by intramuscular injection of killed vaccine $(520 \mu \mathrm{g} / \mathrm{ml}$ heat killed $S$. typhi cells, 250 $\mathrm{\mu l} \mathrm{PBS})$, adjuvant vaccine $(520 \mu \mathrm{g} / \mathrm{ml}$ heat killed $S$. typhi cells, $250 \mu \mathrm{l}$ mineral oil), and DNA vaccine (520 $\mu \mathrm{g} / \mathrm{ml}$ heat killed $S$. typhi cells, $250 \mu \mathrm{l}$ mineral oil and $16 \mu \mathrm{l}$ phage DNA). Each rabbit was bled by cardiac puncture one week after the last injection. All blood samples were incubated at $37^{\circ} \mathrm{C}$ for one hour and then overnight at $4^{\circ} \mathrm{C}$. The serum was separated and stored at $-20^{\circ} \mathrm{C}$. 
Preparation of antiserum in mice: Pathogen-free BALB/c mice were immunized with three doses (each dose after seven days) by intraperitoneal injection of killed vaccine $(4 \mu$ l heat killed $S$. typhi cell, $130 \mu \mathrm{PBS}$ ), adjuvant vaccine ( $4 \mu \mathrm{l}$ heat killed $S$. typhi cells, $150 \mu \mathrm{l}$ mineral oil), and DNA vaccine ( $4 \mu \mathrm{l}$ heat killed $S$. typhi cells, $150 \mu \mathrm{l}$ mineral oil and $8 \mu \mathrm{l}$ phage DNA). Each mouse was decapitated one week after the last injection. All blood samples were incubated at $37^{\circ} \mathrm{C}$ for one hour and then overnight at $4^{\circ} \mathrm{C}$. The serum was separated and stored at $-20^{\circ} \mathrm{C}$.

Wet slide agglutination: Two hundred $\mu \mathrm{l}$ of each serum was mixed with $200 \mu \mathrm{l}$ of antigen in an eppendorf separately and then were incubated at $37^{\circ} \mathrm{C}$. A wet slide was prepared using $50 \mu \mathrm{l}$ of each reaction placed in cavity slide and was observed after 15, 30, 60 and 120 minutes of incubation.

Immnoelecterophoresis: In order to assess the immune response to the phage DNA vaccine, immunization of a group of five rabbits and five Balb/c mice were carried out using intramuscular and intraperitoneal route, respectively. Immunoelectrophoresis was performed on pre-coated agarose slides $(25 \times 75 \mathrm{~mm})$. Ten $\mu$ l of antigen was added to each trough and the diffusion was carried out at room temperature for 48 hours. The slides were washed in distilled water and were stained with coomassie brilliant blue for two hours and destained, overnight.

Coating the ELISA 96 wells plate by antigen: $100 \mu \mathrm{l}$ of S. typhi antigen was added into each well of a 96 well ELISA plate (IWAKI) at a concentration of $1 / 5$ in coating buffer containing $0.15 \%$ $\mathrm{NaCO}_{3}, 0.29 \% \mathrm{NaHCO}_{3}$ at of $\mathrm{pH}$ 9.6. Plates were incubated at $4^{\circ} \mathrm{C}$, overnight. Solution was discarded and $200 \mu \mathrm{l}$ of blocking buffer containing $1 \%$ bovine serum albumin (Promega Co.), $0.02 \%$ tween 20 in PBS (contain $0.8 \% \mathrm{NaCl}, 0.02 \% \mathrm{KCl}, 0.144 \% \mathrm{Na}_{2} \mathrm{HPO}_{4}$ and in deionized water) was added into each well. Plates were incubated at room temperature for one hour where the blocking reagent was discarded and plates were dried at $4^{\circ} \mathrm{C}$. Then each well was washed five times with $200 \mu \mathrm{l}$ of wash buffer containing $0.02 \%$ tween 20 in PBS. Plates were pad dry on paper towel and were stored at $4^{\circ} \mathrm{C}$.

Estimation of total $\gamma$-globulin raised in Rabbit against $S$. typhi antigen by ELISA: Serum sample was diluted $1 / 10$ in EIA buffer containing $0.1 \%$ bovine serum albumin (Promega Co.) and $0.1 \%$ tween 20 (Sigma Co.) in PBS buffer. 100ul of each dilution was incubated in each coated well for one hour after being washed five times with wash buffer containing $0.02 \%$ tween 20 in PBS. Wells were incubated for one hour with $100 \mu \mathrm{l}$ of peroxidase labeled anti-rabbit antibody (Amersham Life-Science) diluted 1/500 in nuclease free water.

Plates were then washed again five times, and the color was developed by using chromogen substrate A solution containing Urea Hydrogen Peroxide and chromogen substrate B solution containing stabilized 3,3'-5,5' Tetramethylbenzidine (TMB) (Autobio Diagnostics Co.). Color reaction was stopped after $10 \mathrm{~min}$ by the addition of $50 \mathrm{\mu l}$ of stop solution containing $1 \mathrm{M}$ sulfuric acid to each well. Optical density at 490nm was measured with the ELISA reader. Positive and negative control sera were included in every reaction.

Estimation of IgG raised in mice antiserum against $S$. typhi antigen by ELISA ( $\mathrm{Fc} / \mathrm{Fab}$ specific as secondary antibody): $10 \mu \mathrm{l}$ of mice antiserum was diluted into 700 $\mu \mathrm{l}$ of EIA buffer and $100 \mu \mathrm{l}$ of this was incubated in a coated well for one hour after being washed five times with wash buffer.

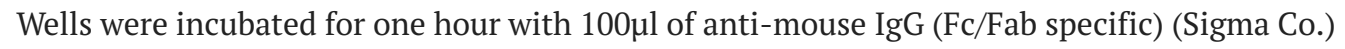
diluted 1:2000 in nuclease-free water. Plate was then washed again five times, and color was developed by using chromogen substrate A sol. and chromogen substrate B sol. Color reaction was stopped after $30 \mathrm{~min}$ by the addition of $50 \mu \mathrm{l}$ of stop solution to each well. Optical density at $490 \mathrm{~nm}$ was measured with the ELISA reader.

Western blotting of total amount of mice and rabbit $\gamma$-globulin against $S$. typhi antigen: PAGE 


\section{Cureus}

gel was run by laemmli's method, $25 \mathrm{~mA}$ and 100 volt and was placed in transfer buffer for 20 min at $4^{\circ} \mathrm{C}$. Blotting sandwich was assembled in blotting cassette. Filter pad, whatman paper, nitrocellulose membrane, polyacrylamide gel, and whatman paper and then filter pad soaked in transfer buffer. Current was flowed from anode to cathode and was left at 35 volt and 90mA, overnight. Membrane was first blocked with $0.5 \%$ dry milk in TBS buffer for two hours at room temperature on rocker. Blot was washed two times with TBS at room temperature on a rocker for $10 \mathrm{~min}$. Gel was stained with commasie blue to insure that the protein was transferred to the membrane. Membrane was treated in primary antibody (1:500 for Rabbit- 1:7000 for Mice) for one hour at room temperature and then was washed with TBS buffer two times. Membrane was incubated in secondary $\mathrm{Ab}$ (1:5000) for one hour at room temperature. Blot was washed with TBS buffer for $15 \mathrm{~min}, 7 \mathrm{ml}$ detection (BCIP/NBT) liquid substrate reagent (Sigma Co.) was added on the blot. The color was developed after $15 \mathrm{~min}$.

Estimation of IgG raised in mice against $S$. typhi antigen by Western Blotting ( $\mathrm{Fc} / \mathrm{Fab}$-specific as secondary antibody): Gel was run by PAGE laemmli's method as mentioned above. Membrane was treated in primary antibody (1:7000) at room temperature overnight and then was washed with TBS buffer two times. Membrane was incubated in secondary Ab IgG-Fab specific (1:5000) for three hours at room temperature.

\section{Results}

In this study, phages were isolated from the urine sample of a patient with UTI. E.coli was detected as an etiological agent of UTI infection. No Pseudomonas was detected. We explored the Host-phage interaction by using the Pseudomonas spp. as bacterial lawn. Plaque assay of filter sterilized urine sample on the lawn of $P 5$ and $P 6$ exhibited remarkable clear plaques due to lytic activity (Figures $1 A, 1 B$ ).

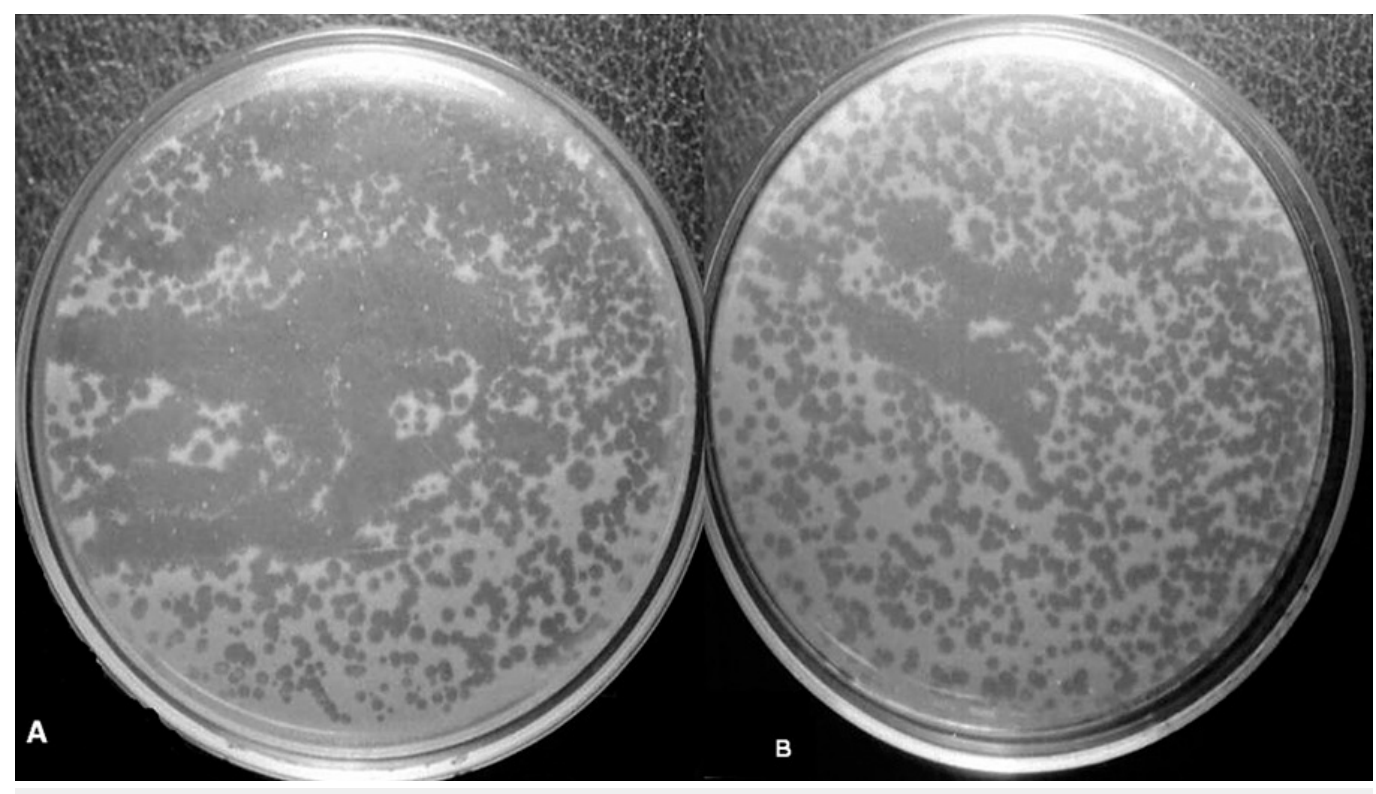

FIGURE 1: Plaque Assay of Lytic Phage on the Lawn of Different Strains of Multiple Drug Resistance Pseudomonas spp

These phages were prorogated as virulent phages in MDR Pseudomonas aeruginosa. Each phage isolated was examined under the electron microscope and was placed in phage families based 


\section{Cureus}

on its morphology as described by Ackerman and colleagues [15]. The electron microscope has indicated the presence of Siphoviridea and Myoviridea like morphology in the lysates (Figures 2A, 2B).
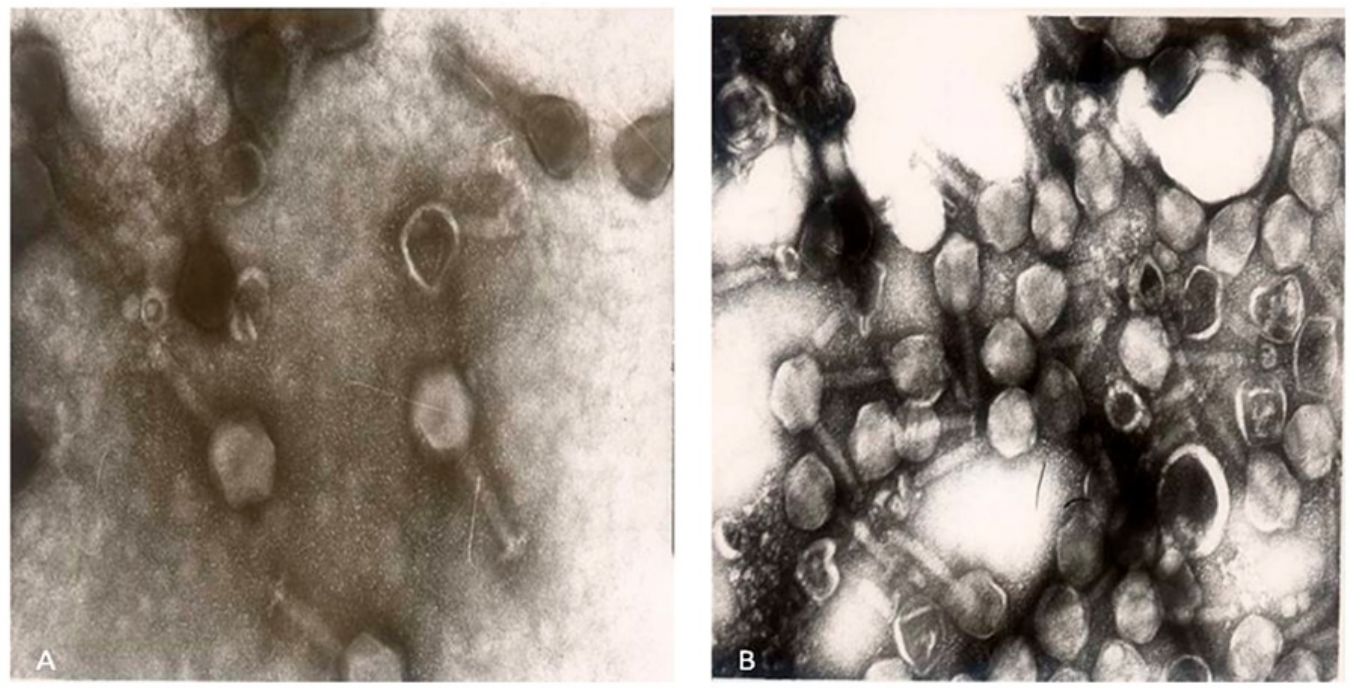

\section{FIGURE 2: Electron Micrographs}

It has been shown that bacterial DNA contain immunostimulatory unmethylated CpG motifs [7]. These motifs rapidly trigger an innate immune response, by the production of IL-6, IL-12 and IFN-gamma. Since DNA vaccines are usually prepared from plasmids of bacterial DNA, we decided to examine the presence of CpG motifs in the genome of PS5 $\Phi$, U9 $\Phi$ and $3 S \Phi$ to determine if $\mathrm{CpG}$ motifs present in these phage genomes may contribute in immunogenicity of DNA vaccines. However, restriction profiles of Msp I and Hpa II has indicated that E.coli Ф (U9) DNA, Ps $\Phi$ (PS5) and 3S E.coli phage isolated from sewage DNA contains several unmethylated CpG motifs sites (Figure 3).

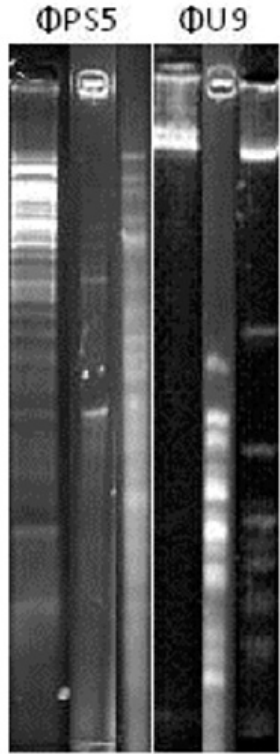

123456
Key:

Lane 1: PS5 $\Phi$ DNA Restriction sites for Msp I Lane 2: PS5 $\Phi$ DNA Restriction sites for Hpa II Lane 3: PS5 $\Phi$ DNA Restriction sites for Hind III Lane 4: U9 $\Phi$ DNA Restriction sites for Msp I Lane 5: U9 $\Phi$ DNA Restriction sites for Hpa II Lane 6: U9 $\Phi$ DNA Restriction sites for Hind III 


\section{Cureus}

\section{FIGURE 3: Restriction Analysis of DNA of Pseudomonas and E.coli phages}

Immunoelectrophoresis of antiserums raised by U9 and PS5 Ф DNA vaccines have shown a strong line of precipitation near cathode which strongly suggest that a high quantity of IgG was produced in both groups of animals which immunized with the $\Phi$ DNA vaccine (Figure 4). Existence of the increased level of IgG antibody against antigens of $S$. typhi has presumably concluded due to the activation of B cells in mice and rabbits (Figure 4).

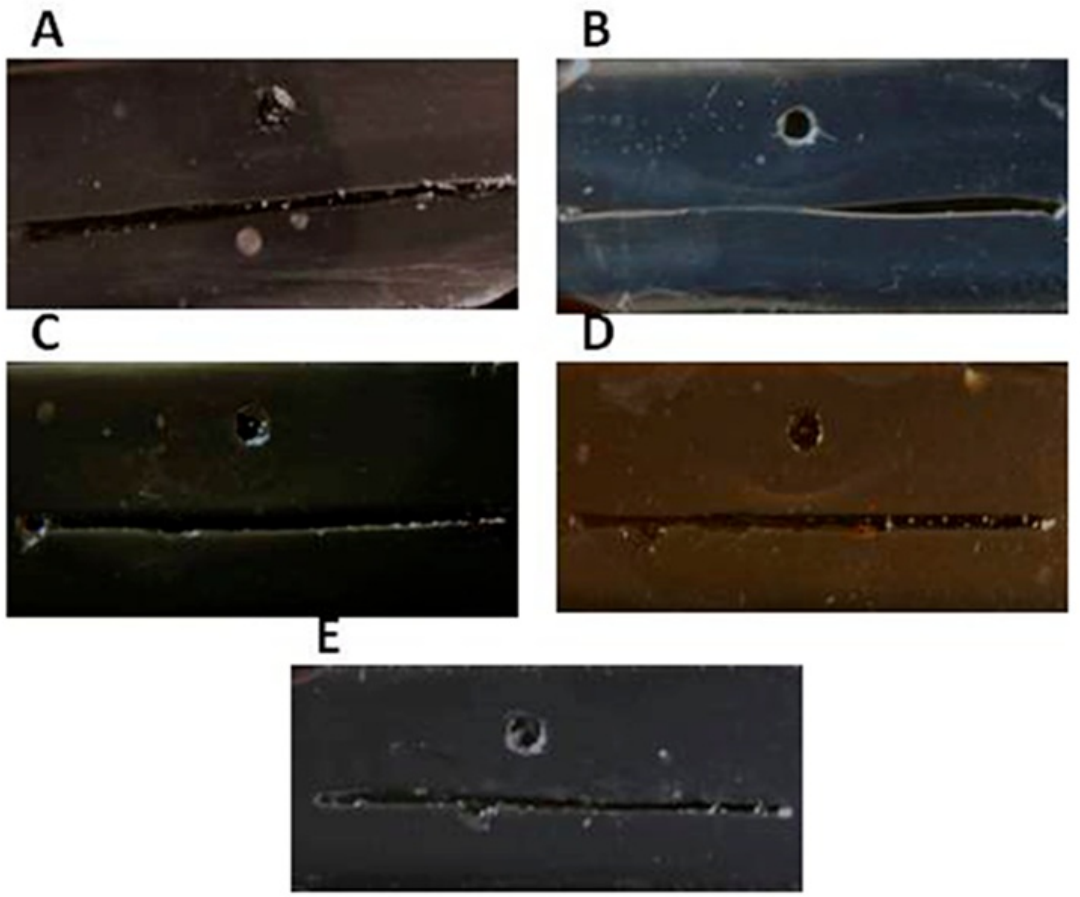

Key:

A: antiserum raised against vaccine + mineral oil + DNA of E.coli phage

$B$ : antiserum raised against vaccine

C: antiserum raised against vaccine + mineral oil

$D$ : antiserum raised against vaccine + minimal oil + DNA of $P$ s phage

E: Control

\section{FIGURE 4: Immunoelectrophoresis}

Our finding is consistent with documented literature [16] that CpG motifs in the DNA sequence has a direct immune stimulatory effect on B cells. These sequences may cause up-regulation of MHC II, B7 and B7.2 collectively [16]. We can conclude that CpG motifs contain Ф DNA that can activate $\mathrm{B}$ cells in mice and rabbits. A large body of evidence on isolated B cells demonstrated that the effect of CpG motifs on B cells is direct in nature [7]. In this study, whole S. typhi antigens were used as a vaccine for the immunization of animals. Comparison of ELISA results of sera from immunized rabbit and mice (Figure $5 \mathrm{~A}$ ) have indicated that $\mathrm{CpG}$ motifs in phage DNA vaccine appeared to stimulate the enhanced immune response as compared to animals immunized by exclusive killed $S$. typhi cells and these along with adjuvant. ELISA of immunized mice sera has confirmed high immunogenicity of phage DNA vaccine by increasing the high 
quality of IgG-Fab specific as compared to IgG-Fc specific (Figure $5 B$ ). The reason for the strong bond in Fab specific reaction was due to multiple interaction sites for antigen and antibody.

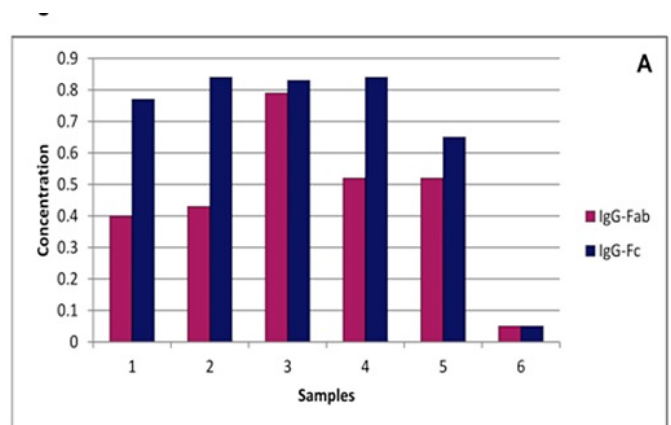

Sample No. 1: Vaccine

Sample No. 2: Vaccine + Mineral Oil

Sample No. 3: Vaccine +Mineral Oil +DNA Ps $\phi$

Sample No. 4: Vaccine +Mineral Oil +DNA E.coli $\phi$

Sample No. 5: Control No. 6: Blank

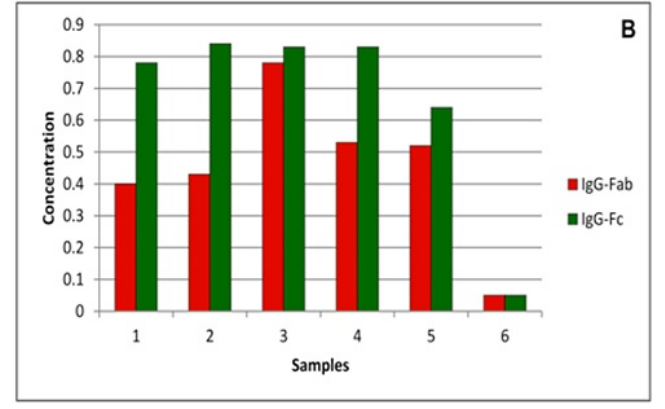

Sample No. 1: Vaccine + Mineral Oil

Sample No. 2: Vaccine + DNA of Ps. $\phi$

Sample No. 3: Vaccine + Mineral Oil + DNA of Ps. $\phi$

Sample No.4: Vaccine + Mineral Oil+ DNA of E.coli $\phi$

Sample No.5: Control No.6: Blank

\section{FIGURE 5: ELISA}

Comparison of Western blotting results of immunized mice has shown significantly enhanced yield of $\gamma$-globulin-Fab against Vi and LPS antigens and low yield of $\mathrm{H}$ antigen were observed in animals immunized by $\Phi$ DNA vaccine. After the addition of mineral oil in DNA vaccine, significant amount of Ab against $\mathrm{H}$ antigen were being produced. Ps. $\Phi$ DNA vaccine elicited the immune response against all $S$. typhi antigens whereas E. coli $\Phi$ DNA vaccine exhibited strong immune response against LPS antigens.

B cell activation by CpG DNA shows strong synergy with signaling through the B cell receptor, such as stimulatory effect of CpG DNA would tend to promote the development of antigenspecific immune response against associated antigens, which would be of obvious benefit in adjuvant vaccine development [7].

\section{Discussion}

In the present study, IgG-Fab/Fc was used as secondary antibodies. In order to determine the specificity of IgG fragments, the Fc fragment has shown less specificity to Vi and LPS, compared to Fab since anti-Fab antibody (used as secondary antibody) bound strongly to these antigens has further confirmed the specific humoral response in mice.

Subsequent assays for the determination of specific antibody response in immunized mice with Fab and Fc fragments of IgG as secondary antibodies by ELISA and Western blotting have shown perfect correlation. It has been documented [19] that the Fc fragment does not bind to Ags but acts as initiation of the complement cascade, a process that leads to the lysis of the target cells or mediates phagocytosis [20-21].

Comparative study has indicated that, stimulatory effect of E.coli $\Phi$ (U9) DNA and Ps. Ф (PS5) DNA contains CpG motifs in rabbit and mice has shown a shift toward the B cell activation response. Based on these results, it can be hypothesized that $\mathrm{CpG}$ motifs has implicated enhanced B cell activation. These results demonstrated that comparable B cells activation by E.coli $\Phi$ DNA was less than Ps. $\Phi$ DNA. This difference in immune response may be associated with Hind III restriction profile of Ps. $\Phi$ DNA which indicated the existence of additional $\mathrm{CpG}$ island consequently pronounced IgG yield. 


\section{Conclusions}

Based on our results, responses both quantitatively and qualitatively were evaluated in animals immunized by DNA vaccine. This means the protection level and also adaptive immunity might be enhanced by CpG contained $\Phi$ DNA administration. Our findings are consistent with similar studies [17] has proved activation of innate immunity by exposing mice to the single dose of CpG DNA provide long-term protection (for two weeks) against multiple pathogens, including Listeria monocytogenes, Francisells tubarsis, Anthrax, ebola, malaria, Leshmania, and Schisoma [18,22-23]. In the current study, we were unable to determine the prolonged (more than six weeks) protective effect of immunized animals due to scarification of them for antisera. However, this study demonstrates, for the first time, that $\mathrm{CpG}$ motifs in phage genomes are efficacious as immunostimulants in mice and rabbit, as the number of studies indicated CpG-motifs have been effective in controlling intracellular protozoa, bacteria and viruses. This is the first report showing CpG-motifs-containing phage genome to be effective against bacterial disease in animal models.

\section{Additional Information}

\section{Disclosures}

Human subjects: All authors have confirmed that this study did not involve human participants or tissue. Animal subjects: The PCMD (Panjwani Center for Molecular Medicine and Drug) Research Institute Issued protocol number N/A. Conflicts of interest: In compliance with the ICMJE uniform disclosure form, all authors declare the following: Payment/services info: All authors have declared that no financial support was received from any organization for the submitted work. Financial relationships: All authors have declared that they have no financial relationships at present or within the previous three years with any organizations that might have an interest in the submitted work. Other relationships: All authors have declared that there are no other relationships or activities that could appear to have influenced the submitted work.

\section{Acknowledgements}

We would like to acknowledge Dr. Adib H. Rizvi for allowing us to use the Transmission Electron Microscope to analyze our samples. We further thank Dr. Qasim Mehdi for the use of the ELISA Reader in KIBGE. We greatly appreciate the assistance given by Leslie Johnson for editing the manuscript.

\section{References}

1. Krieg AM, Yi AK, Matson S, Waldschmidt TJ, Bishop GA: CpG motifs in bacterial DNA trigger direct B-cell activation. Nature. 1995, 347:546-549.

2. Pisetsky D.S: Immuno activation by bacterial DNA: A new genetic code . Immunity. 1996, 5:303-310.

3. Klinman DM, Yi AK, Beaucage SL, Conover J, Krieg AM: CpG motifs expressed by bacterial DNA rapidly induce lymphocytes to secrete IL-6, IL-12 and IFN pro. Proc Natl Acad Sci U S A. 1996, 93:2879-2883.

4. Halpern MD, Kurlander RJ, Pisetsky DS: DNA induces murine interferon-g production by stimulation of interleukin-12 and tumor necrosis factor-cell. 1996, 167:72-78.

5. Cowdery JS, Chace JH, Yi AK, Krieg AM: Bacterial DNA induces NK cells to produce IFNgamma in vivo and increases the toxicity of lipopolysaccharides. 1996, 156:4570-4575.

6. Davis HL, Weeratna R, Waldschmidt TJ, Tygrett L, Schorr J, Krieg AM: CpG DNA is a potent enhancer in mice immunized with recombinant hepatitis B surface antigen. Immuno. 1998, 160:870-876.

7. Scheule RK: The role of CpG motifs in Immunostimulation and gene therapy . Adv Drug Deliv Rev. 2000, 44:119-134. 
8. Sato Y, Roman M, Tighe H, Lee D, Corr M, Nguyen MD, Silverman GJ, Lotz M, Carson DA, Raz $\mathrm{E}$ : Immunostimulatory DNA sequences necessarily for effective intradermal gene immunization. Science. 1996, 273:352-354.

9. Weeratna RD, Makinen SR, McCluskie MJ, Davis HL: TLR agonists as vaccine adjuvants: comparison of CpG ODN and Resiquimod (R-848). Vaccine. 2005, 23:5263-5270.

10. Yoon HA, Eo SK: Differential polarization of immune responses by genetic cotransfer of chemokines changes the protective immunity of DNA vaccine against pseudorabies virus. J.Immunology. 2007, 120:182-191.

11. Douglas B. Lowrie, Robert G. Whalen: DNA vaccines: methods and protocols. Springer, New York; 1999.

12. Gratia A: Numerical Relations between Lysogenic Bacteria and Particles of Bacteriophage . Ann. Inst. Pasteur. 1936, 57:652.

13. Hershey AD, Kalmanson G, Bronfenbrenner J: Quantitative Methods in the Study of the Phage-Antiphage Reaction. J. Immunol. 1943, 46:267-273.

14. Jones D, Krueger AP: A Rapid Slide Plaque Technic for Bacteriophage Assay . J. Gen Physiol. 1951, 34:347-357.

15. Ackermann HW: Phage classification and characterization. Methods Mol Biol. 2009, 501:127140.

16. Roman M, Martin-Orozco E, Goodman JS, Nguyen MD, Sato Y, Ronaghy A, Kornbluth RS, Richman DD, Carson DA, Raz E: Immunostimulatory DNA sequences function as T-helper-1promoting adjuvant. Nature med. 1997, 3:849-854.

17. Krieg AM: The role of CpG motifs in innate immunity . Curr Opin Immunol. 2000, 12:35-43.

18. Barrow P, Lovell M, Berchieri A Jr.: Use of lytic bacteriophage for control of experimental Escherichia coli septicemia and meningitis in chickens and calves. Clin Diagn Lab Immunol. 1998, 5:294-298.

19. Brüssow H: Phage therapy: the Escherichia coli experience. Microbiology. 2005, 151:21332140.

20. Mirano-Bascos D, Steede NK, Robinson JE, Landry SJ: Influence of disulfide-stabilized structure on the specificity of helper T-cell and antibody responses to HIV envelope glycoprotein gp120. J Virol. 2010, 84:3303-3311. 10.1128/JVI.02242-09

21. Skurnik M, Strauch E: Phage therapy: facts and fiction. Int J Med Microbiol. 2006, 296:5-14.

22. Biswas B, Adhya S, Washart P, Paul B, Trostel AN, Powell B, Carlton R, Merril CR: Bacteriophage therapy rescues mice bacteremic from a clinical isolate of vancomycin-resistant Enterococcus faecium. Infect. Immun. 2002, 70:204-210.

23. McVay CS, Velásquez M, Fralick JA: Phage Therapy of Pseudomonas aeruginosa Infection in a Mouse Burn Wound Model. Antimicrob Agents Chemother. 2007, 51:1934-1938.

24. Mansfield JM, Bagasra O: Lymphocyte function in experimental African trypanosomiasis I. B cell responses to helper T cell-independent and -dependent antigens. J Immunology. 1978, 120:759-765. 